\title{
Understanding faculty and student perceptions about reward and advancement: survey of four STEM departments at research intensive universities
}

Data in this report collected, prepared, and analyzed by: Holly Cho, Researcher

Principal Investigator: Julie Risien, Associate Director, Oregon State University, STEM Research Center 


\section{Executive Summary}

This report summarizes the results of a survey exploring four STEM departments that have engaged in meaningful reforms in academic systems of reward and advancement including promotion and tenure (P\&T). The survey was administered as part of a study seeking to expose the strengths and challenges of reform efforts by understanding the lived experiences of faculty and graduate trainees. The four departments are relatively large ( $>40$ faculty), and are situated in public, very high research activity (Carnegie R1) institutions located in relatively small, suburban or rurally-situated college towns in the Northwest and Midwest United States. It aims to provide insights into faculty and student perceptions of and experiences with departmental level practices. University leaders and those working on national-scale initiatives to improve reward and advancement in higher education may find these results useful.

Findings in this report highlight perceptions of study participant volunteers at four institutions selected for positive reform efforts. They should not be taken as generalizable, rather indicative of conditions within the departments represented.

- Participants engage in a variety of academic activities; decisions to participate in outreach were primarily motivated by desire to advocate for science and serve the needs of others and not driven by professional recognition, norms or values.

- Choices to engage different academic activities appear to be driven by personal satisfaction and opportunities for advancement over institutional values or disciplinary norms.

- Faculty generally agree that promotion and tenure processes are fair, but have some concerns about transparency. Specific policies that promote mentorship and openness about reward and advancement processes are appreciated and desired.

- Faculty members who participate in P\&T committees vary widely within and across institutions in their evaluation standards - from holistic, entirely qualitative evaluations to entirely quantitative, metric-based evaluations.

- A majority of graduate student participants indicated they will seek work outside of academia upon completing their degrees.

- Nearly all student participants engage in service activities (e.g. outreach, committees, clubs, etc.), but some engage discreetly because they do not feel supported by mentors.

The next phase of this study will explore tenured professors from minoritized and underrepresented groups in academia to expose parts of the system ripe for change that can better align the practices of reward and advancement to the espoused values of universities. 


\section{Table of Contents}

EXECUTIVE SUMMARY

TABLE OF CONTENTS

TABLE OF FIGURES

STUDY OVERVIEW

SURVEY PARTICIPANTS

OVERALL RESPONSES

PROFESSIONAL ACTIVITIES

PROFESSIONAL ACTIVITIES AND ADVANCEMENT 10

EQUITY $\quad 11$

\begin{tabular}{lc} 
FACULTY SPECIFIC RESPONSES & 12 \\
\hline
\end{tabular}

EXPECTATIONS FOR FACULTY 12

MENTORSHIP OF FACULTY 12

BELIEFS RELATED TO PROMOTION AND TENURE 13

FACULTY BELONGING AND SELF-EFFICACY 14

ASSESSMENT OF PROMOTION AND TENURE

FACULTY SERVICE ACTIVITIES

TIME ALLOCATION

\begin{tabular}{lr} 
GRADUATE STUDENTS & 19 \\
\hline
\end{tabular}

EXPECTATIONS FOR GRADUATE STUDENTS 20

GRADUATE STUDENT BELIEFS RELATED TO PROFESSIONAL ADVANCEMENT 21

GRADUATE STUDENT BELONGING AND SELF-EFFICACY 23

GRADUATE STUDENT SERVICE ACTIVITIES 24

THEMES FROM OPEN-ENDED RESPONSES BY FACULTY 26

INFORMATION ABOUT PROMOTION AND TENURE 26

MOTIVATIONS FOR PARTICIPATING IN SERVICE 26

FEEDBACK ON THE TENURE PROCESS 27

\begin{tabular}{ll} 
CONCLUSIONS & 28 \\
\hline
\end{tabular} 


\section{Table of Figures}

FiguRE 1. SURVEY RESPONDENTS' PARTICIPATION AND SATISFACTION RATES FOR SELECT PROFESSIONAL ACTIVITIES. BLUE BARS SHOW THE PERCENTAGE OF RESPONDENTS WHO PARTICIPATE IN EACH ACTIVITY. ORANGE DOTS EXPRESS THE PERCENTAGE OF PEOPLE WHO SELECTED THE ACTIVITY AS ONE OF THE TWO MOST SATISFYING ACTIVITIES OUT OF THE TOTAL NUMBER OF RESPONDENTS WHO

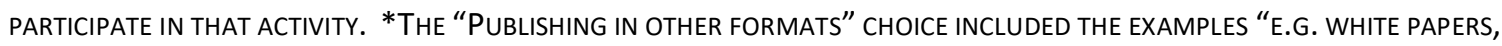
TECHNICAL REPORTS, PUBLIC MEDIA."

FIGURE 2. HEAT-MAP SHOWING THE RELATIVE IMPORTANCE OF DIFFERENT FACTORS IN RESPONDENTS' DECISIONS TO PARTICIPATE IN VARIOUS PROFESSIONAL ACTIVITIES. IMPORTANCE SCORES ARE A COMPOSITE MEASURE THAT COMBINES MEAN IMPORTANCE RANKING AND FREQUENCY OF FACTOR-SELECTION.

FIGURE 3. IMPORTANCE OF SELECT PROFESSIONAL ACTIVITIES TO RESPONDENTS' PROFESSIONAL ADVANCEMENT ............................10

FIGURE 4. RESPONDENT OPINIONS ON ISSUES PERTAINING TO DEPARTMENTAL EQUITY ( $N=79$ ).

FIGURE 5. FACULTY BELIEFS ABOUT THE CLARITY OF RESPONSES RELATING TO THE CLARITY OF EXPECTATIONS FROM THEIR DEPARTMENTS REGARDING THEIR PROFESSIONAL OUTPUT IN RESEARCH ( $N=33)$, TEACHING $(N=28)$, AND SERVICE $(N=29)$.

FIGURE 6. FACULTY RESPONSES REGARDING THE FAIRNESS AND TRANSPARENCY OF PROMOTION AND TENURE PRACTICES $(\mathrm{N}=34)$. .........13

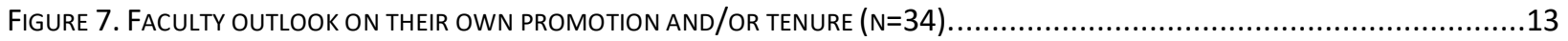

FIGURE 8. FACULTY RESPONSES REGARDING THE EXTENT TO WHICH THEY FEEL WELCOMED AND SUPPORTED BY THEIR DEPARTMENTS $(\mathrm{N}=34)$.

FIGURE 9. FACULTY RESPONSES REGARDING THEIR INTEGRATION INTO THEIR DEPARTMENTS AND SELF-EFFICACY RELATED TO DEPARTMENTAL CHANGE ( $\mathrm{N}=34)$.

FIGURE 10. THE RANGE IN DECISION-MAKING MEASURES FOR FACULTY WHO HAVE SERVED ON PROMOTION AND TENURE COMMITTEES ( $N=14$ ), WITH 1 REPRESENTING AN ENTIRELY QUALITATIVE REVIEW, AND 10 REPRESENTING AN ENTIRELY QUANTITATIVE REVIEW..15

Figure 11. The RELATIVE IMPORTANCE OF SERVICE ACTIVITIES TO FACULTY PROFESSIONAL ADVANCEMENT ( $N=34)$.

FIGURE 12. FACULTY OPINIONS REGARDING THE ROLE OF SERVICE ACTIVITIES IN THEIR PROFESSIONAL WORK (N=34).

FIGURE 13. DEPICTING THE RANGE IN PERCENT DIFFERENCE BETWEEN THE AMOUNT OF TIME FACULTY SPEND ON RESEARCH, TEACHING, SERVICE, AND OTHER PROFESSIONAL ACTIVITIES AND THE TIME FORMALLY ALLOCATED FOR THOSE ACTIVITIES IN THEIR POSITION DESCRIPTIONS.

FIGURE 14. GRADUATE STUDENT RESPONSES REGARDING THEIR FUTURE CAREER INTENTIONS ( $\mathrm{N}=62$ ). THIS QUESTION WAS ONE OF THE FIRST PRESENTED TO RESPONDENTS, AND AS SUCH, THE SAMPLE SIZE FOR THE FOLLOWING QUESTIONS IS SMALLER, REFLECTING ATTRITION LATER IN THE SURVEY.

FIGURE 15. GRADUATE STUDENT OPINIONS REGARDING DEPARTMENTAL EXPECTATIONS FOR THEIR DEGREE COMPLETION (N=41)........20

FIGURE 16. GRADUATE STUDENT OPINIONS REGARDING THE TRANSPARENCY AND FAIRNESS OF PROFESSIONAL ADVANCEMENT IN THEIR FIELD ( $N=41)$.

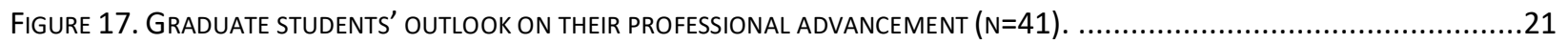

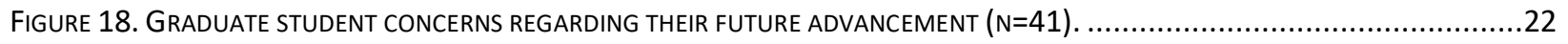

FIGURE 19. GRADUATE STUDENT RESPONSES REGARDING THEIR SENSE OF WELCOMING AND SUPPORT IN THEIR DEPARTMENTS (N=41)...23

FIGURE 20. GRADUATE STUDENT SENSE OF INTEGRATION AND SELF-EFFICACY RELATED TO DEPARTMENTAL CHANGE $(\mathrm{N}=41) . . . . . . . . . . .23$

FIGURE 21. SERVICE-RELATED ACTIVITIES IN WHICH GRADUATE STUDENTS PARTICIPATE. STUDENTS WERE ASKED TO SELECT ALL ACTIVITIES

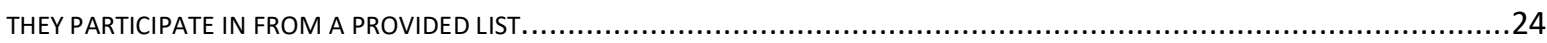

Figure 22. GRAdUATE STUdENT BELIEFS RELATED TO THE IMPACT OF SERVICE ACTIVITIES ON THEIR ACADEMIC WORK (N=36) AND THE EXTENT TO WHICH THEY EXERCISE DISCRETION ABOUT THEIR SERVICE ACTIVITIES ( $N=35)$. 


\section{Study Overview}

This report summarizes the results of a survey exploring potential avenues for reform in promotion and tenure processes at four STEM discipline departments at public universities in the United States. The survey was administered as part of a study seeking to identify and characterize exemplars of promotion and tenure reform at the departmental scale to expose the strengths and challenges of reform efforts through understanding the lived experiences of faculty and graduate trainees.

The four surveyed departments were identified through a lengthy nomination process that pointed to more than 30 university departments where reforms were underway. However, when investigating actual reforms at the departmental level only 12 departments both fit our initial criteria ${ }^{1}$ and committed to be interviewed on the topic. Of those interviewed, 8 were not included in this study for a variety of reasons including reward and advancement processes that did not break any known norms in the disciplines, chair/head decision not to pursue study, and small numbers of ranked faculty preventing researchers from adequately protecting the identity of respondents. The final departments were assessed by the research team as making positive and significant progress toward reforms.

The four departments included share some characteristics that should be considered in reviewing the data. All departments are relatively large ( $>40$ faculty) situated in large, public, very high research activity (Carnegie R1) institutions. The four departments are considered in the STEM disciplines. The institutions are located in relatively small, suburban or rurallysituated college towns in Northwest and Midwest United States.

\footnotetext{
${ }^{1}$ Initial criteria for departments: a) known for making positive progress toward reforming promotion and tenure through policy and practice; $b$ ) have implemented reforms in one or more of the following domains: public engagement/science communication, policy processes, broadening participation in science, teaching improvement, mentoring practices, multidisciplinary collaboration, industry or other community partnerships; c) have robust graduate student and postdoc training; c) explicitly aspire to broaden diversity in their faculty and students; and d) have chairs or heads who will vigorously support the study and will encourage broad participation of departmental faculty, students and professional staff.
} 


\section{Survey Participants}

The survey was distributed to four departments at different public universities. Graduate students, post-doctoral researchers, tenured/tenure-track faculty, and professional/non-tenure track faculty were all invited to participate in the survey. The survey was open for 1-month and closed with 103 individual responses that were counted as valid. Given the nature of the sample, it is important to recognize that this report provides a description of data collected from four departments at four universities that have been engaging in thoughtful reform of promotion and tenure in the United States. It serves to illustrate the landscape of opinion, but should not be considered generalizable beyond the survey respondents and scope of this report.

Survey responses were counted as valid if answers were recorded for the first substantive question in the survey after general participant information (e.g. location, department, position, etc.). Of the 103 valid responses, 79 responses are complete, with all questions answered. Attrition during survey-taking is a common phenomenon and is not indicative of any atypical reaction to this particular survey.

Table 1. The number of survey responses by professional position.

PROFESSIONAL POSITION

\begin{tabular}{c|c}
\hline GRADUATE STUDENT & 53 \\
POST-DOCTORAL RESEARCHER & 9 \\
TENURE-TRACK, PRE-TENURE FACULTY & 8 \\
TENURED FACULTY & 19 \\
PROFESSIONAL FACULTY/NON-TENURE TRACK FACULTY & 14 \\
TOTAL & $\mathbf{1 0 3}$ \\
\hline
\end{tabular}

The majority of survey responses came from graduate students, who comprised $51 \%$ of the sample. Post-doctoral researchers accounted for $9 \%$ of responses. Due to this small sample size, post-docs are not included with any sub-category of responses in this report. Faculty made up the remainder of the sample (40\%), with tenured faculty comprising the largest proportion of faculty, followed by professional faculty/non-tenure track faculty. The majority of respondents identified as white females, followed by white males.

Table 2. Participant demographics

\begin{tabular}{c|ccccc} 
& FEMALE & MALE & NON-BINARY & PREFER NOT TO SAY & TOTAL \\
\hline $\begin{array}{c}\text { WHITE } \\
\begin{array}{c}\text { A PERSON-OF- } \\
\text { COLOR }\end{array}\end{array}$ & 32 & 28 & 0 & 0 & $\mathbf{6 0}$ \\
$\begin{array}{c}\text { PREFER NOT } \\
\text { TO SAY }\end{array}$ & 1 & 6 & 0 & 1 & $\mathbf{1 2}$ \\
TOTAL & $\mathbf{3 8}$ & $\mathbf{3 6}$ & $\mathbf{0}$ & 4 & $\mathbf{7}$ \\
\hline
\end{tabular}




\section{Overall responses}

\section{Professional activities}

Survey respondents participate in a variety of professional activities. The most common activities are research activities - publishing in peer-reviewed academic journals and collaboration - and teaching undergraduate students. Despite the frequency of teaching as a professional activity, engaging in professional development activities to improve teaching was relatively uncommon, with fewer than $40 \%$ of respondents indicating that this was something that they did. This, along with service to government agencies and/or policy engagement and industry partnerships and/or entrepreneurial activities were in the bottom three of activities.

Survey respondents were also asked to select two activities that brought them the most personal satisfaction. The three most frequently selected items were: collaboration within the respondent's field, and teaching/mentorship of graduate and undergraduate students.

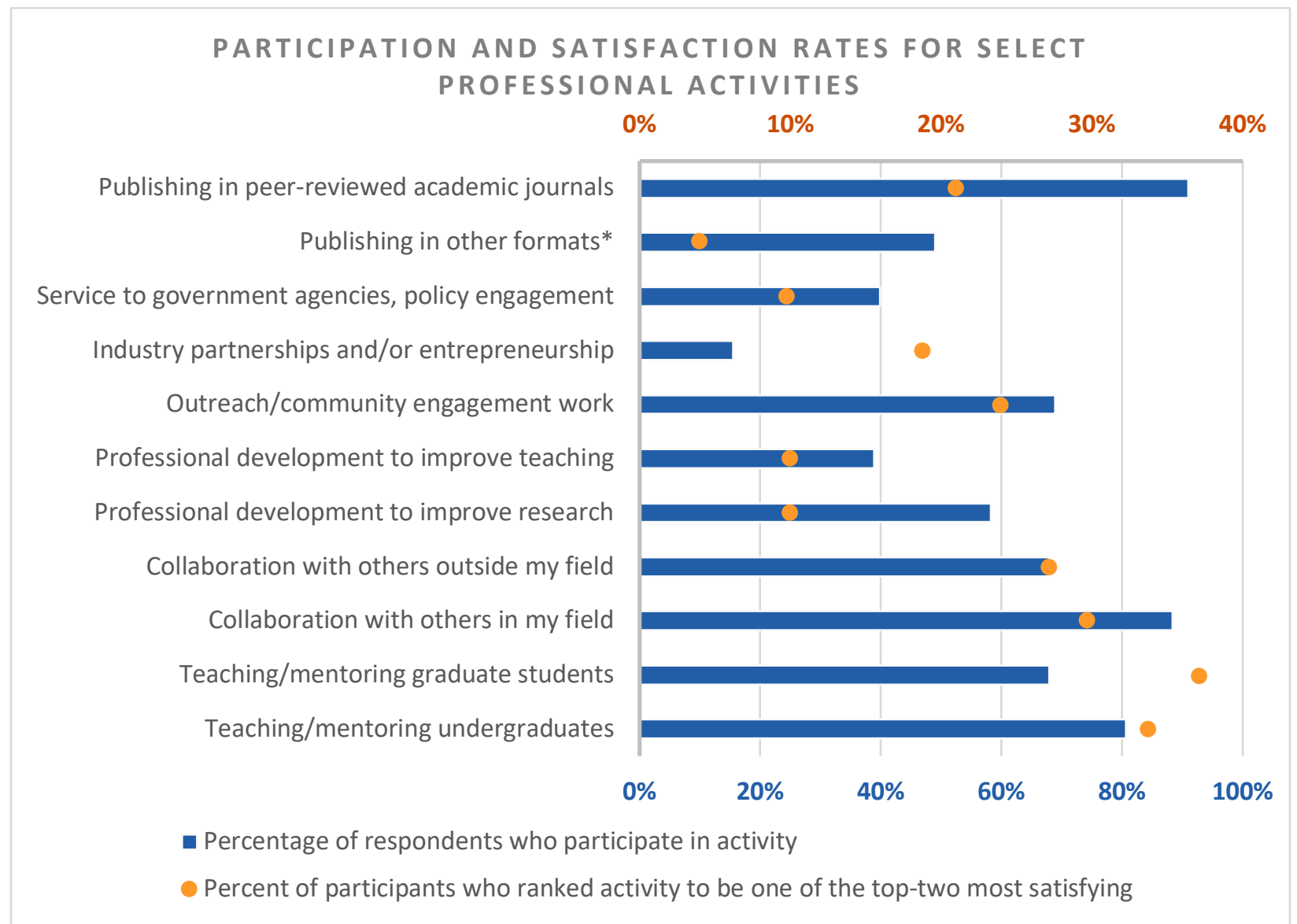

Figure 1. Survey respondents' participation and satisfaction rates for select professional activities. Blue bars show the percentage of respondents who participate in each activity. Orange dots express the percentage of people who selected the activity as one of the two most satisfying activities out of the total number of respondents who participate in that activity. *The "Publishing in other formats" choice included the examples "e.g. white papers, technical reports, public media." 
Greater rates of satisfaction were expressed for certain professional activities over others. Teaching and mentorship of graduate students and undergraduate students were the two most frequently rated activities. "Publishing in other formats", which included the examples "white papers, technical reports, public media", had the lowest relative satisfaction rates. Similarly, despite being the most frequent activity, publishing in peer-reviewed academic journals was chosen as a superlatively satisfying activity with only moderate frequency. Notably, "industry partnerships and/or entrepreneurship" was the least common professional activity, but was considered to be satisfying by a relatively high number of those who participate in this.

\begin{tabular}{|c|c|c|c|c|c|c|c|}
\hline Factor & Collaboration & Publishing & $\begin{array}{l}\text { Professional } \\
\text { Development }\end{array}$ & $\begin{array}{l}\text { Teaching } \\
\text { and } \\
\text { Mentoring }\end{array}$ & Outreach & $\begin{array}{c}\text { Entreprene- } \\
\text { urship }\end{array}$ & $\begin{array}{l}\text { Government } \\
\text { service }\end{array}$ \\
\hline $\begin{array}{l}\text { Advancing } \\
\text { science }\end{array}$ & & & & & & & \\
\hline $\begin{array}{l}\text { Advocating } \\
\text { for science }\end{array}$ & & & & & & & \\
\hline $\begin{array}{l}\text { Professional } \\
\text { advancement }\end{array}$ & & & & & & & \\
\hline $\begin{array}{c}\text { Serving } \\
\text { others' needs }\end{array}$ & & & & & & & \\
\hline $\begin{array}{c}\text { Personal } \\
\text { satisfaction }\end{array}$ & & & & & & & \\
\hline $\begin{array}{l}\text { Networking } \\
\text { with others }\end{array}$ & & & & & & & \\
\hline $\begin{array}{l}\text { Professional } \\
\text { recognition }\end{array}$ & & & & & & & \\
\hline $\begin{array}{l}\text { Getting or } \\
\text { maintaining } \\
\text { funding }\end{array}$ & & & & & & & \\
\hline $\begin{array}{c}\text { Departmenta } \\
\text { norms }\end{array}$ & & & & & & & \\
\hline $\begin{array}{c}\text { The norms of } \\
\text { my field }\end{array}$ & & & & & & & \\
\hline $\begin{array}{l}\text { Institutional } \\
\text { values }\end{array}$ & & & & & & & \\
\hline $\begin{array}{c}\text { Most } \\
\text { important }\end{array}$ & & & & & & & $\begin{array}{l}\text { Least } \\
\text { important }\end{array}$ \\
\hline
\end{tabular}

Figure 2. Heat-map showing the relative importance of different factors in respondents' decisions to participate in various professional activities. Importance scores are a composite measure that combines mean importance ranking and frequency of factor-selection. 
In order to understand how survey respondents make decisions about what professional activities to engage in, we asked them to select and rank the specific factors that influence their professional choices to participate in government service, entrepreneurship, outreach, teaching/mentoring, professional development, publishing, and collaboration. The frequency at which a particular factor was selected was used to weight the average ranking that it received ( Figure 2).

Some factors, such as personal satisfaction or departmental norms, were generally linked equally to most professional activities. However, others were more specific. For example, professional recognition is not a driving factor for most activities, but does influence decisions about publishing. Likewise, "serving the needs of others" and "advocating for science" are both factors that strongly influence outreach work and teaching/mentoring in particular, while "advancing science" is a major influence on publishing and collaboration. These results suggest that different professional activities serve different, and non-overlapping needs of graduate students, post-docs, and faculty. 


\section{Professional activities and advancement}

Participants were asked about the importance of various professional duties specifically in terms of their professional advancement. Basic research in their discipline was regarded universally as an important activity. Collaborative research across disciplines was generally rated as very to extremely important. Teaching and mentoring undergraduates and graduate students were both considered moderately important on average, though undergraduate teaching and mentorship rated higher than graduate teaching and mentorship. Engaged research with non-academic partners was considered slightly important, on average.

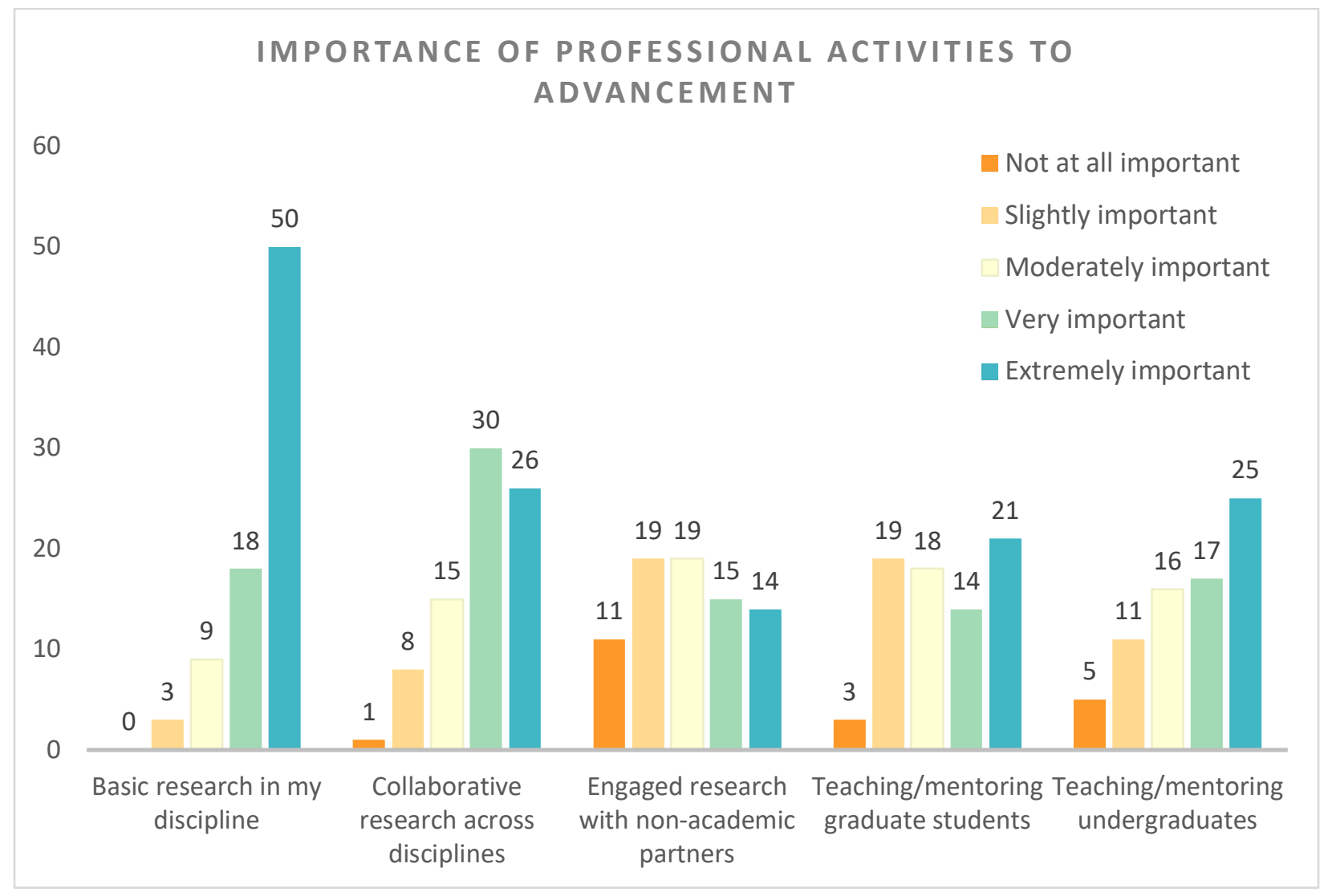

Figure 3. Importance of select professional activities to respondents' professional advancement. 
Equity

Participants reported feeling positive regarding equity-related issues. Most participants felt that they were evaluated fairly by their department, regardless of their personal identity, and that their success in the department was not limited by their identities. In addition, most participants agreed that their department was actively working to improve diversity and equity among faculty and staff.

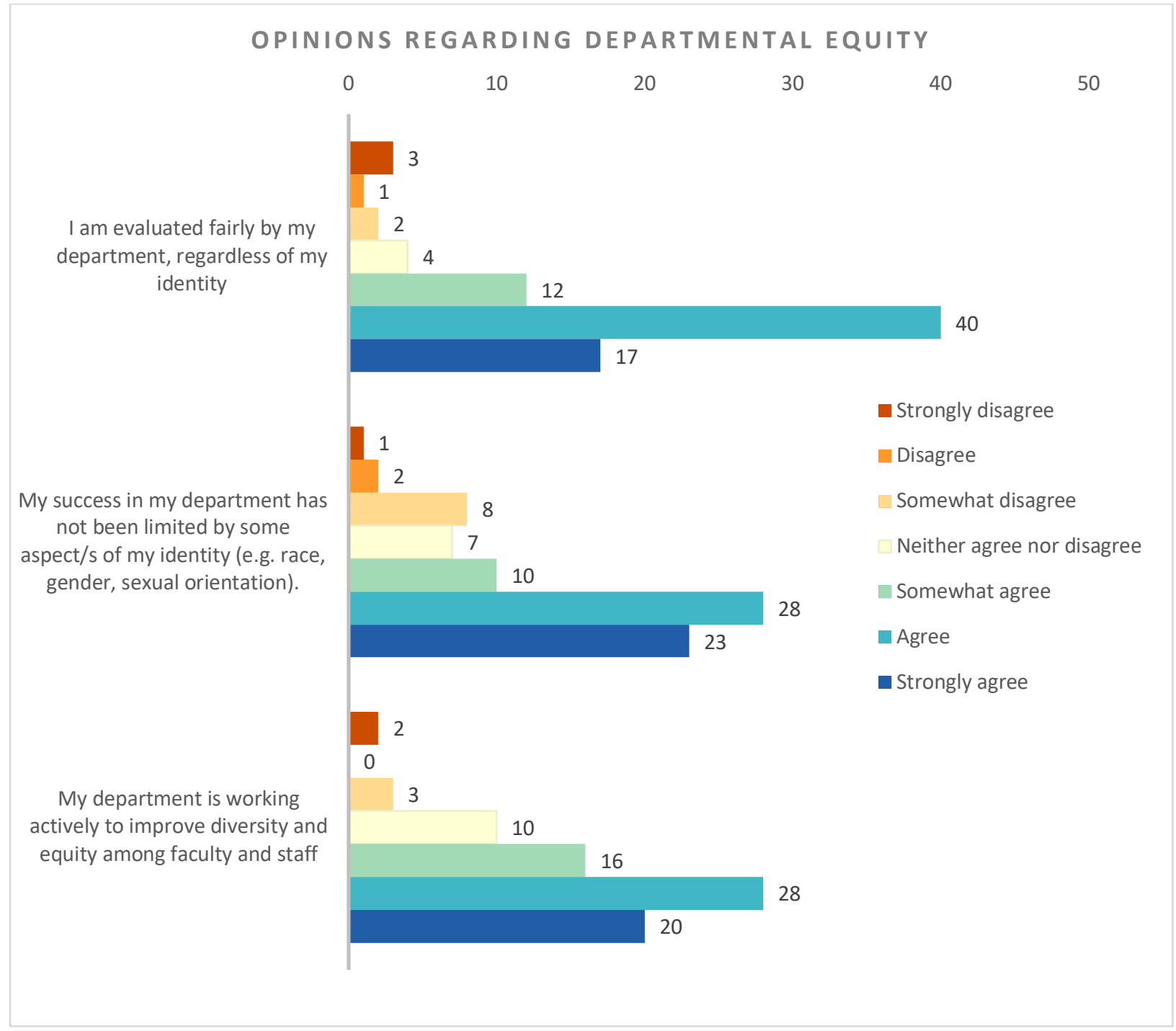

Figure 4. Respondent opinions on issues pertaining to departmental equity $(n=79)$. 


\section{Faculty specific responses}

Faculty members were asked an additional set of questions related to their experience in promotion and tenure processes. This group included tenured faculty; tenure-track, pre-tenure faculty; and professional/non-tenure track faculty.

\section{Expectations for faculty}

Faculty respondents generally believe that their departments have clear expectations for their professional output. On average, faculty were more likely to believe that their department had clearer expectations for teaching $(n=28)$ and service $(n=29)$ than for research output $(n=33)$.

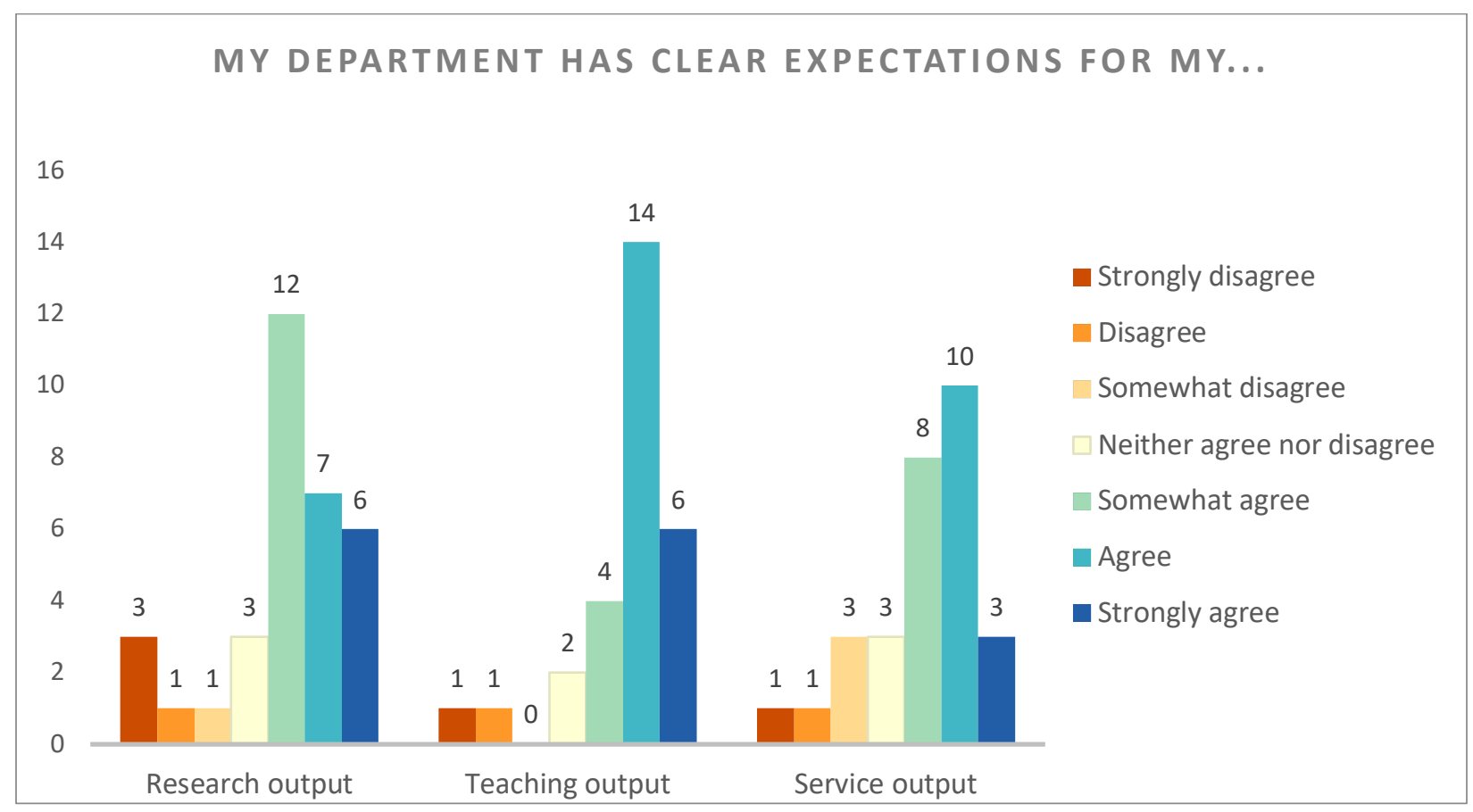

Figure 5. Faculty beliefs about the clarity of responses relating to the clarity of expectations from their departments regarding their professional output in research $(n=33)$, teaching $(n=28)$, and service $(n=29)$.

Mentorship of faculty

Most faculty (tenured, pre-tenure tenure-track, and professional/non-tenure track) report that they have some form of formal or informal mentorship. Of 34 faculty who responded to this set of questions, 15 receive both, 5 receive only formal mentorship, 8 receive only informal mentorship, and 6 report receiving neither. 
Although faculty generally agree that promotion and tenure processes are fair, they are more equivocal regarding the transparency of these processes.

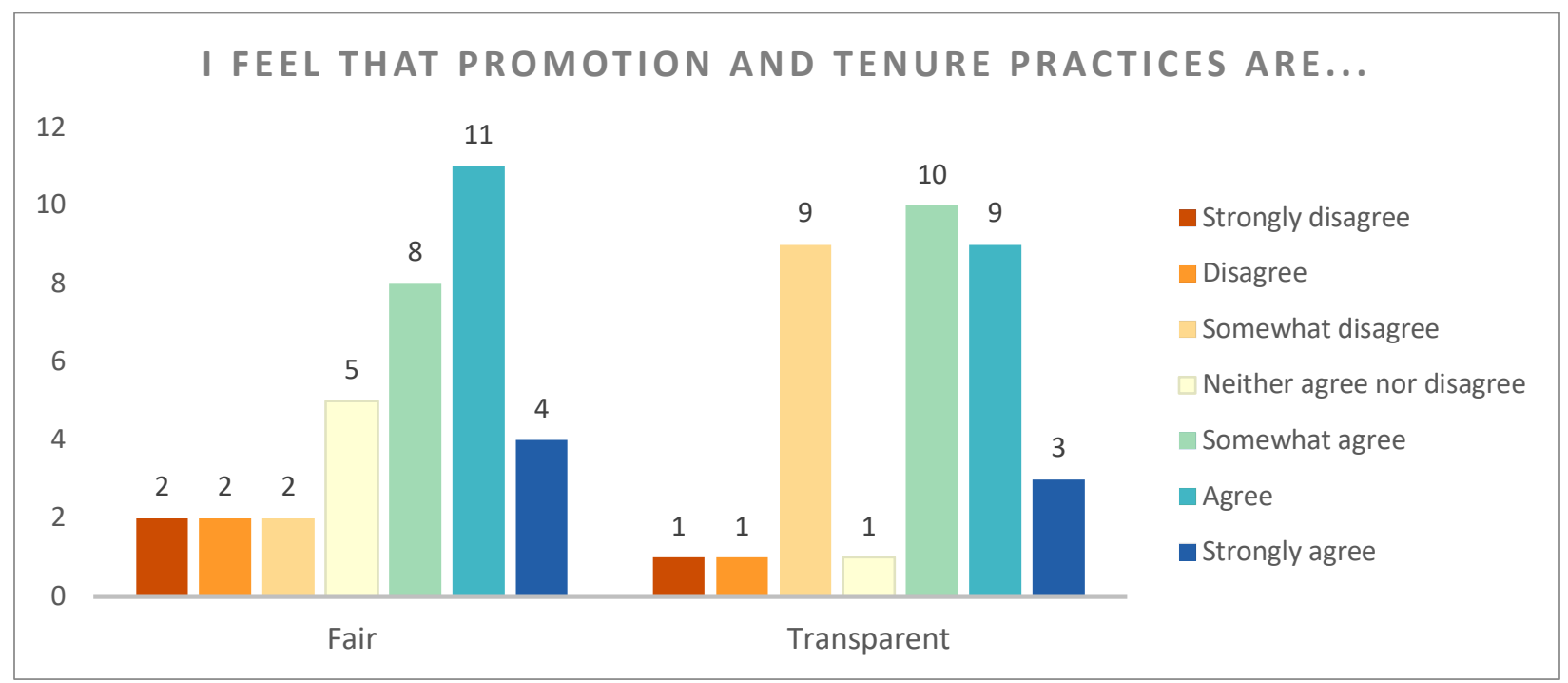

Figure 6. Faculty responses regarding the fairness and transparency of promotion and tenure practices $(n=34)$.

Faculty respondents are also generally positive in their outlook on their own promotion and tenure potential. On average, there was agreement with statements related to their optimism about P\&T processes and their self-efficacy related to earning promotions and/or tenure.

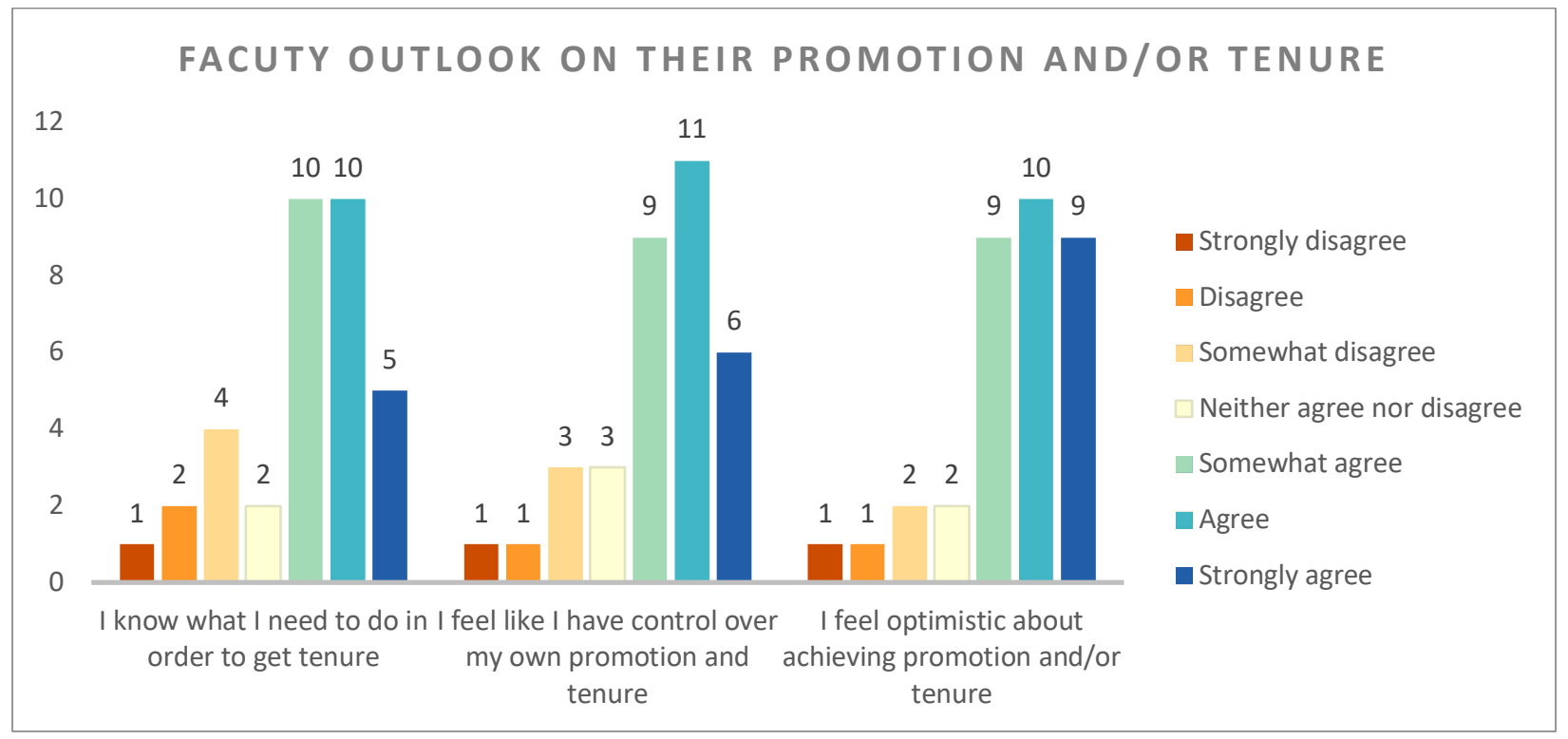

Figure 7. Faculty outlook on their own promotion and/or tenure $(n=34)$. 
Faculty report feeling welcomed and supported by both faculty in their departments and their department heads (or equivalent).

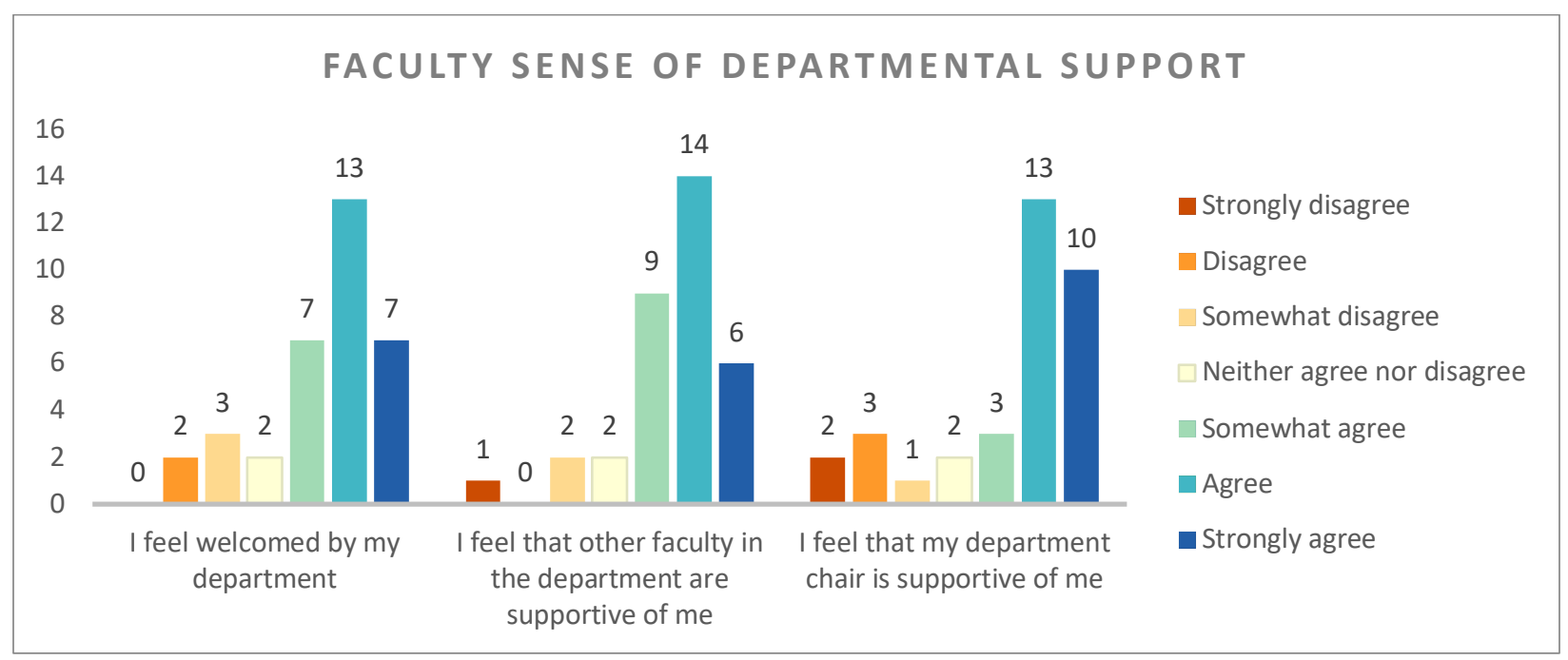

Figure 8. Faculty responses regarding the extent to which they feel welcomed and supported by their departments $(n=34)$.

In contrast to a high degree of welcoming and support, there was less consensus regarding how integrated faculty feel integrated into their department. Unlike a sense of welcoming and support, integration reflects the extent to which a faculty member identifies with the department or the extent to which they feel the department's identity reflects their own.

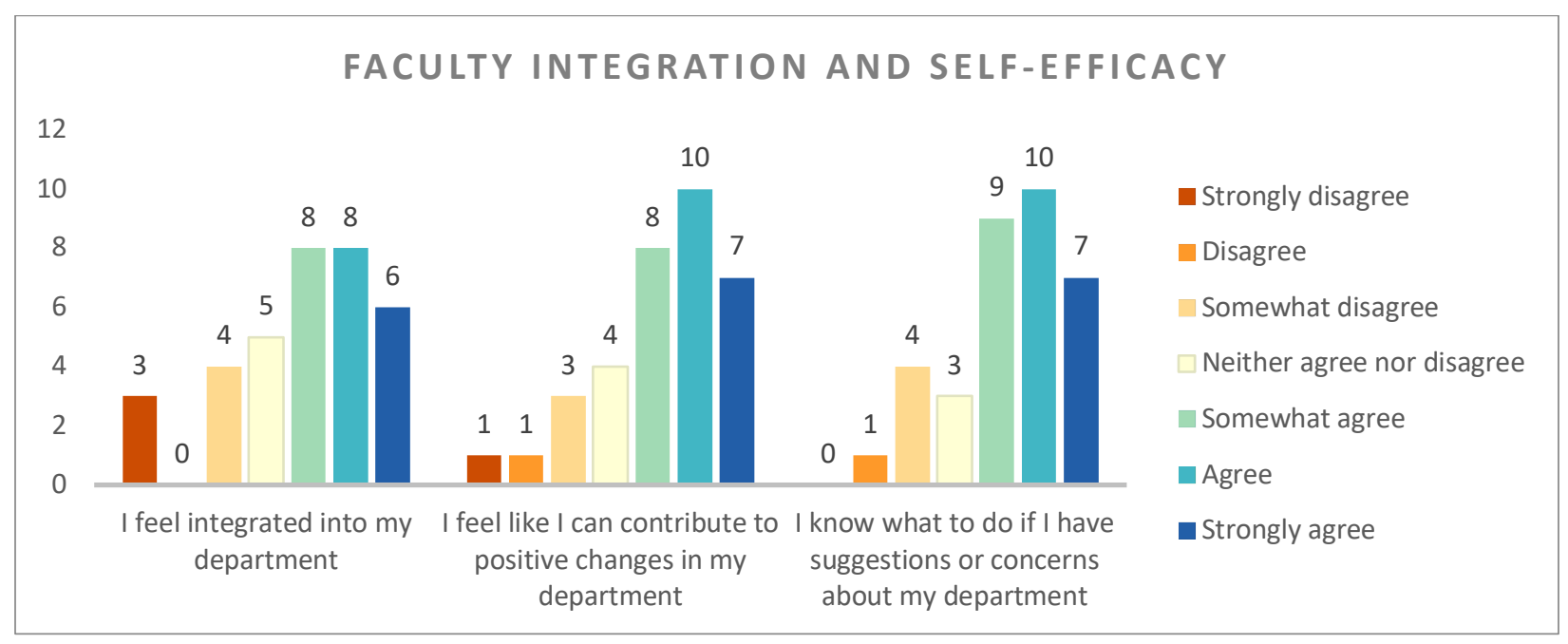

Figure 9. Faculty responses regarding their integration into their departments and self-efficacy related to departmental change $(n=34)$. 
Fourteen of the surveyed faculty members reported that they had previously served on a promotion and tenure committee. These faculty were also asked to rate, on a scale of 1-10, how they made their decisions about promotion and tenure, with 1 being "Entirely qualitative; based on the depth and quality of work and its value to the discipline and society", and 10 being "Entirely quantitative; candidates must meet a specific set of metrics". Although the mean rating was about 4.7, representing an equal mix of both quantitative and qualitative measures, the ratings ranged widely, from 2-8.8. This suggests that despite work that has been done to clarify the way that promotion and tenure decisions are made, there is still variation between individuals in the way they make decisions.

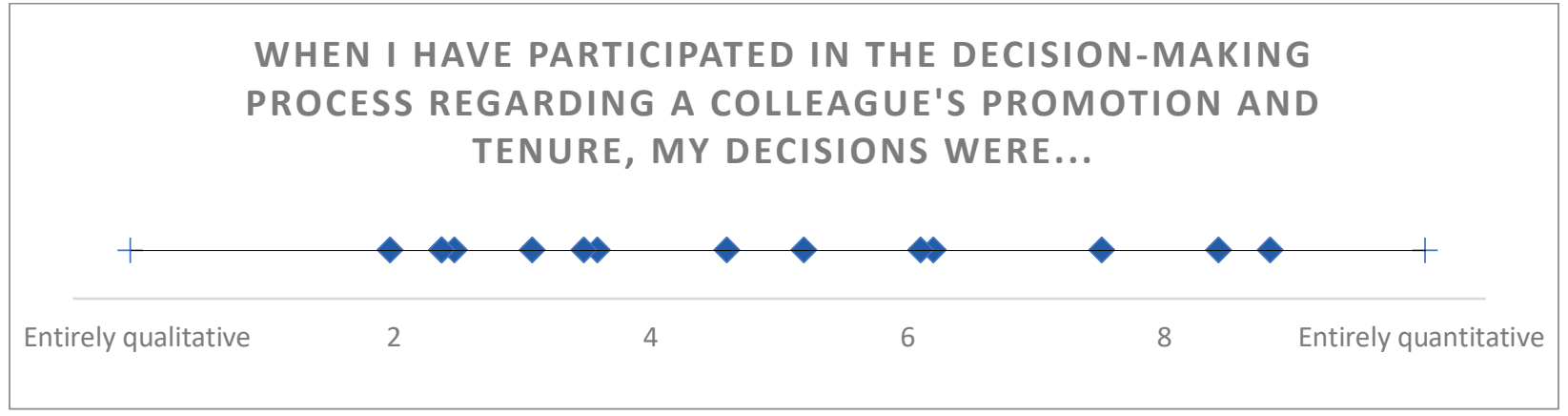

Figure 10. The range in decision-making measures for faculty who have served on promotion and tenure committees $(n=14)$, with 1 representing an entirely qualitative review, and 10 representing an entirely quantitative review. 
In contrast to research and teaching activity (Figure 4), service is generally considered less important to professional advancement, and certain activities are not universally considered to constitute service. Of the 41 faculty who took the survey, $n=31$ reported that serving on departmental and/or college committees constituted service, $n=23$ reported as such for serving on institutional committees or initiatives, $n=12$ for faculty mentorship, $n=18$ for community engagement and outreach, and $n=27$ for service on external initiatives. Faculty who reported consideration of a particular activity to be service were subsequently asked how important that activity was to their professional advancement.

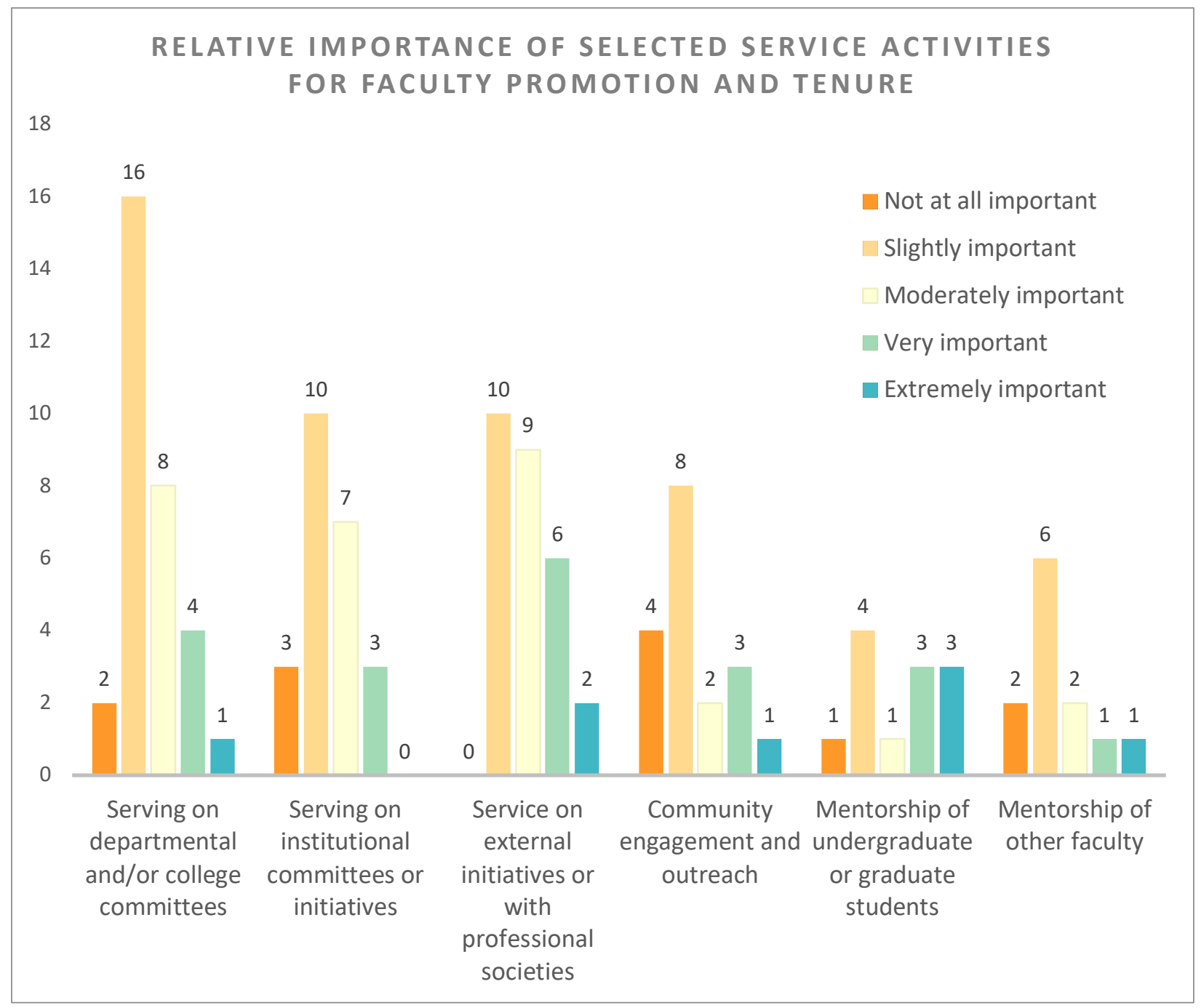

Figure 11. The relative importance of service activities to faculty professional advancement $(n=34)$. 
Although service activities are generally agreed to be professionally and/or personally enriching, faculty did report, on average, that service activities took valuable time that would be better spent doing other work, a reflection of the relatively low reported importance of service activities in advancement.

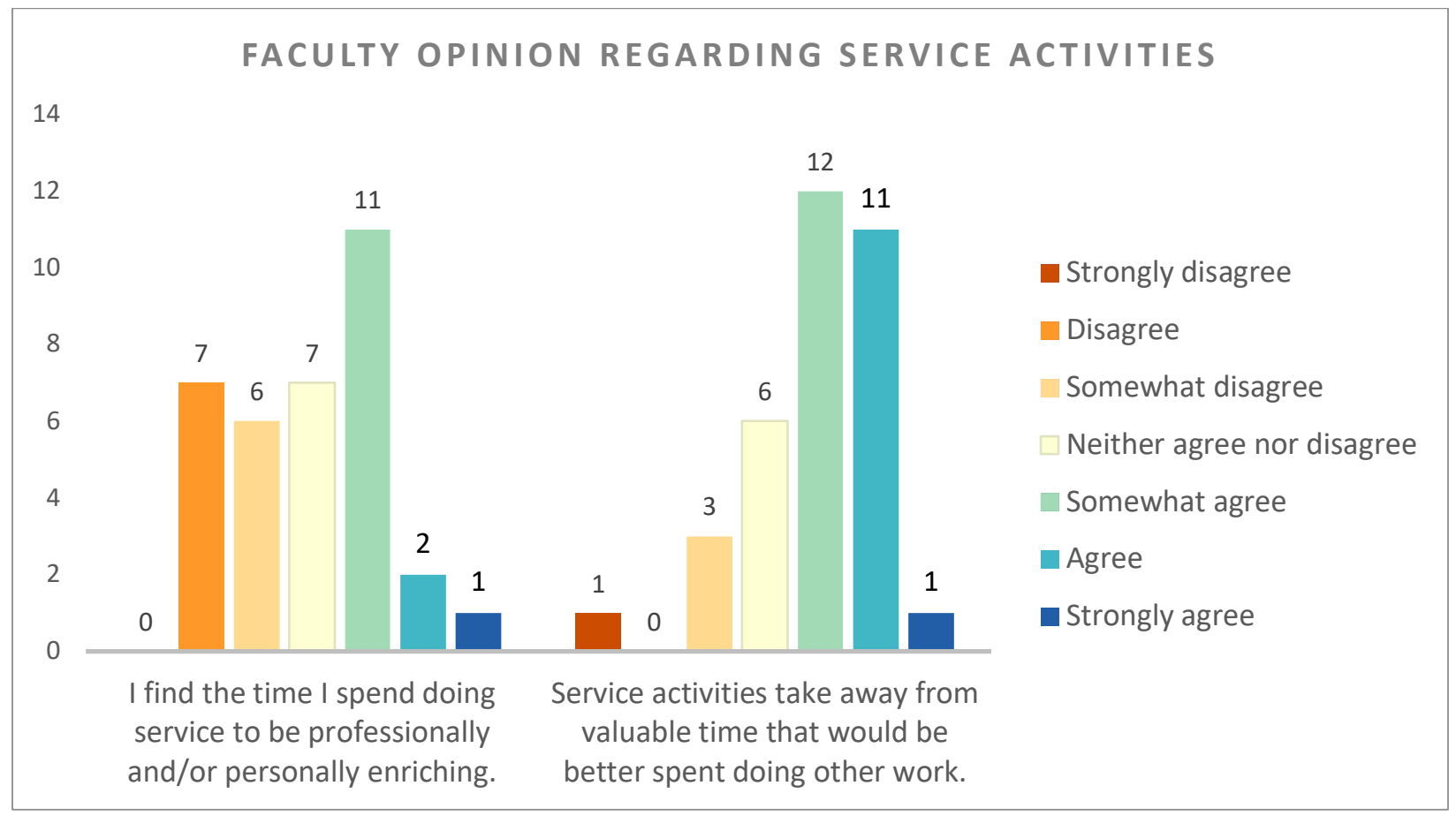

Figure 12. Faculty opinions regarding the role of service activities in their professional work $(n=34)$. 


\section{Time allocation}

Of the 42 faculty members surveyed, 27 allocated their time differently than what was stated in their formal position description. In these cases, faculty were generally more likely to spend less time teaching than formally allocated for, and more time doing service than formally allocated for. Differences in research time allocation were more varied across faculty - there were similar numbers of faculty who spent more time than allocated for research as there were those who spent less time than allocated.

Figure 13. Depicting the range in percent difference between the amount of time faculty spend on research, teaching, service, and other professional activities and the time formally allocated for those activities in their position descriptions.

In general, professional/non-tenured faculty $(n=14)$ spent less time on research and teaching than formally allocated and more time performing service activities. Of these, $n=4$ did not diverge from their formal time allocation. Tenure track faculty $(n=8)$ generally spend more time doing research and less time teaching or doing service than allocated; $n=2$ did not diverge from their formal time allocation. In cases where tenured faculty $(n=20)$ conducted less research $(n=$ 9), they were more likely to make up this time by performing service activities. In cases where they conducted more research $(n=6)$, this time typically cut into time allocated for teaching. The remaining 5 faculty did not diverge from their formal time allocation. 


\section{Graduate students}

Graduate students $(n=53)$ were strongly represented in the sample. They were asked studentspecific questions pertaining to their feelings about their graduate training and professional advancement.

A majority of graduate students indicated a desire to seek work outside of academia upon completing their degrees $(42 \%, n=26)$. Twenty-one students $(34 \%)$ intend to stay in academia, while another 15 (24\%) of students were unsure. This fairly clear divide in student respondents' future intentions should be kept at the forefront when considering the following results.

STUDENT FUTURE INTENTIONS

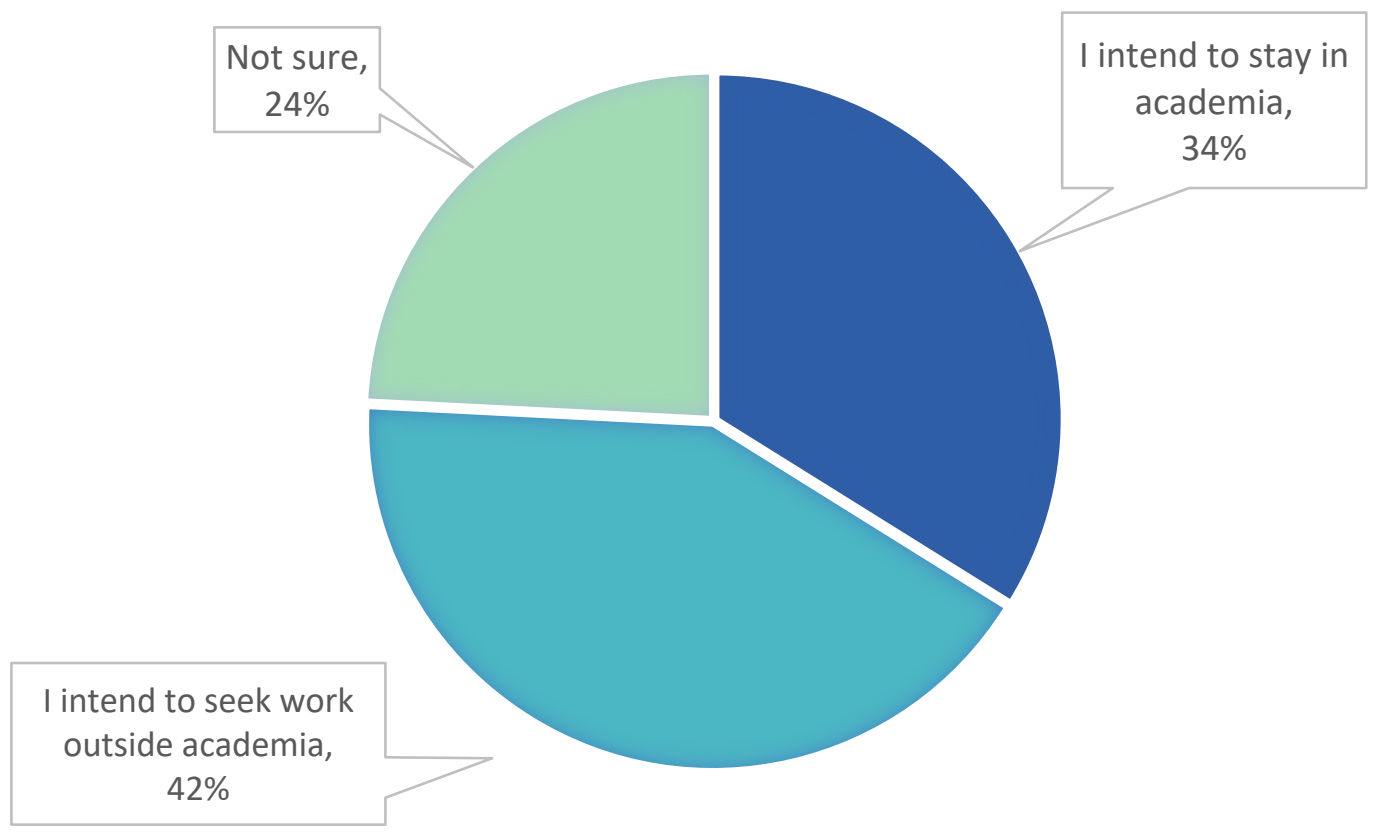

Figure 14. Graduate student responses regarding their future career intentions $(n=62)$. This question was one of the first presented to respondents, and as such, the sample size for the following questions is smaller, reflecting attrition later in the survey. 
Graduate students generally agree that their department has clear expectations for what they need to do in order to complete their degrees, and that those expectations are fair.

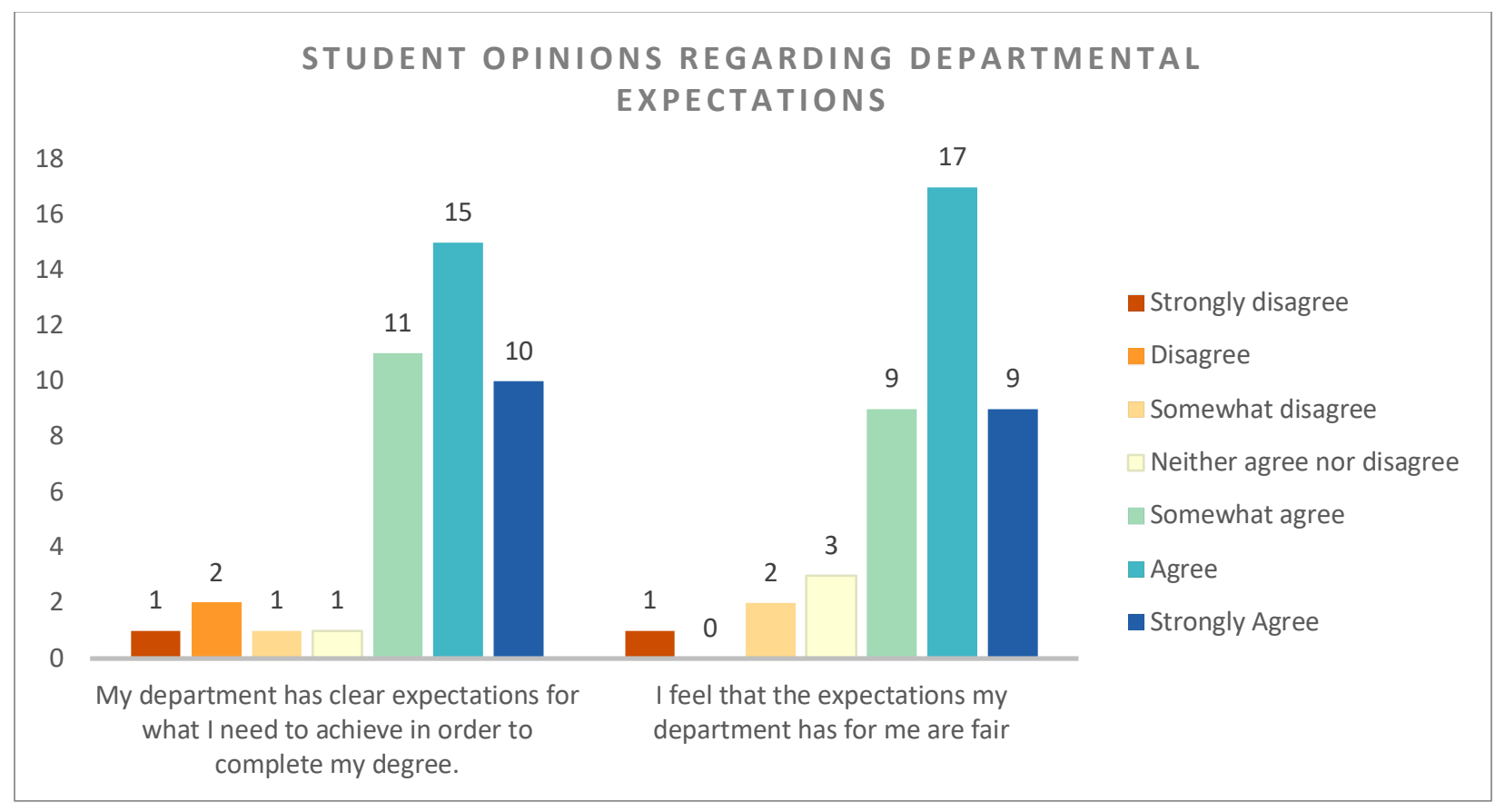

Figure 15. Graduate student opinions regarding departmental expectations for their degree completion $(n=41)$. 
On average, graduate students neither agree nor disagree that professional advancement in their fields is transparent or fair.

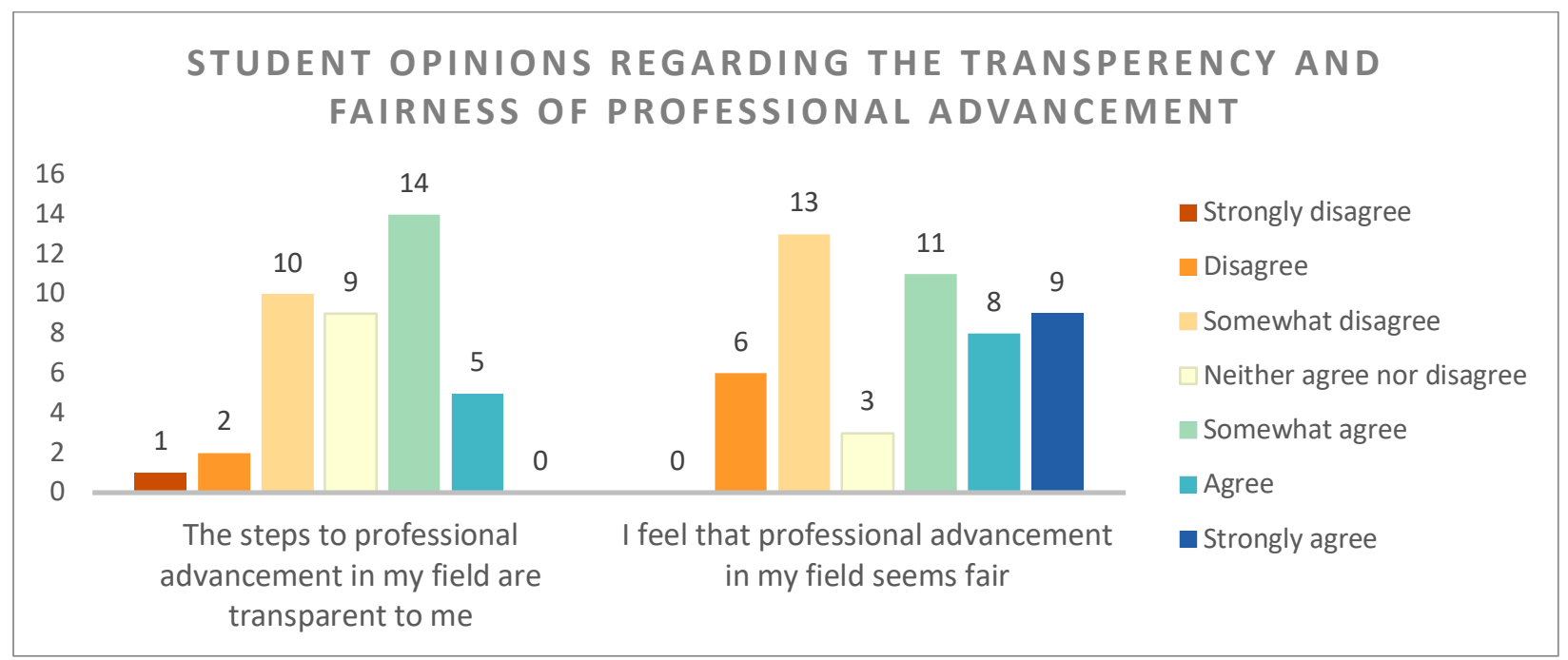

Figure 16. Graduate student opinions regarding the transparency and fairness of professional advancement in their field $(n=41)$.

Regardless of graduate student beliefs regarding the transparency or fairness of professional advancement, graduate students generally agree that they are optimistic about their professional advancement and believe that they know what it takes to achieve a tenured faculty position in their field. It is important to keep in mind that $25 \%$ of student respondents to the survey do not intend to remain in academia, and thus their "professional advancement" is not related to university promotion and tenure processes.

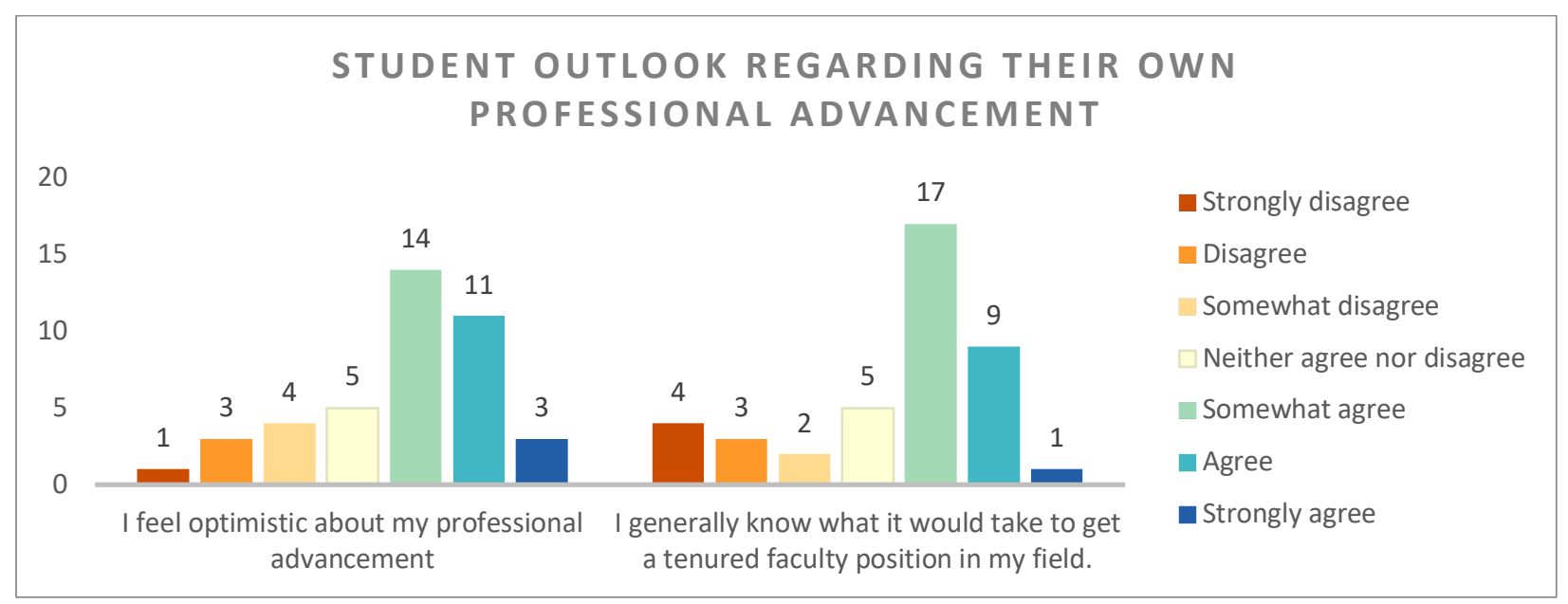

Figure 17. Graduate students' outlook on their professional advancement ( $n=41)$. 
However, despite a relatively positive outlook on their future in their disciplines, graduate students are equivocal about whether or not they have control over their own professional advancement and report agreement with the statement "I worry about whether I will be able to advance in my field after I graduate" (Figure 18). This aligns with student responses regarding the fairness and transparency of professional advancement in their fields.

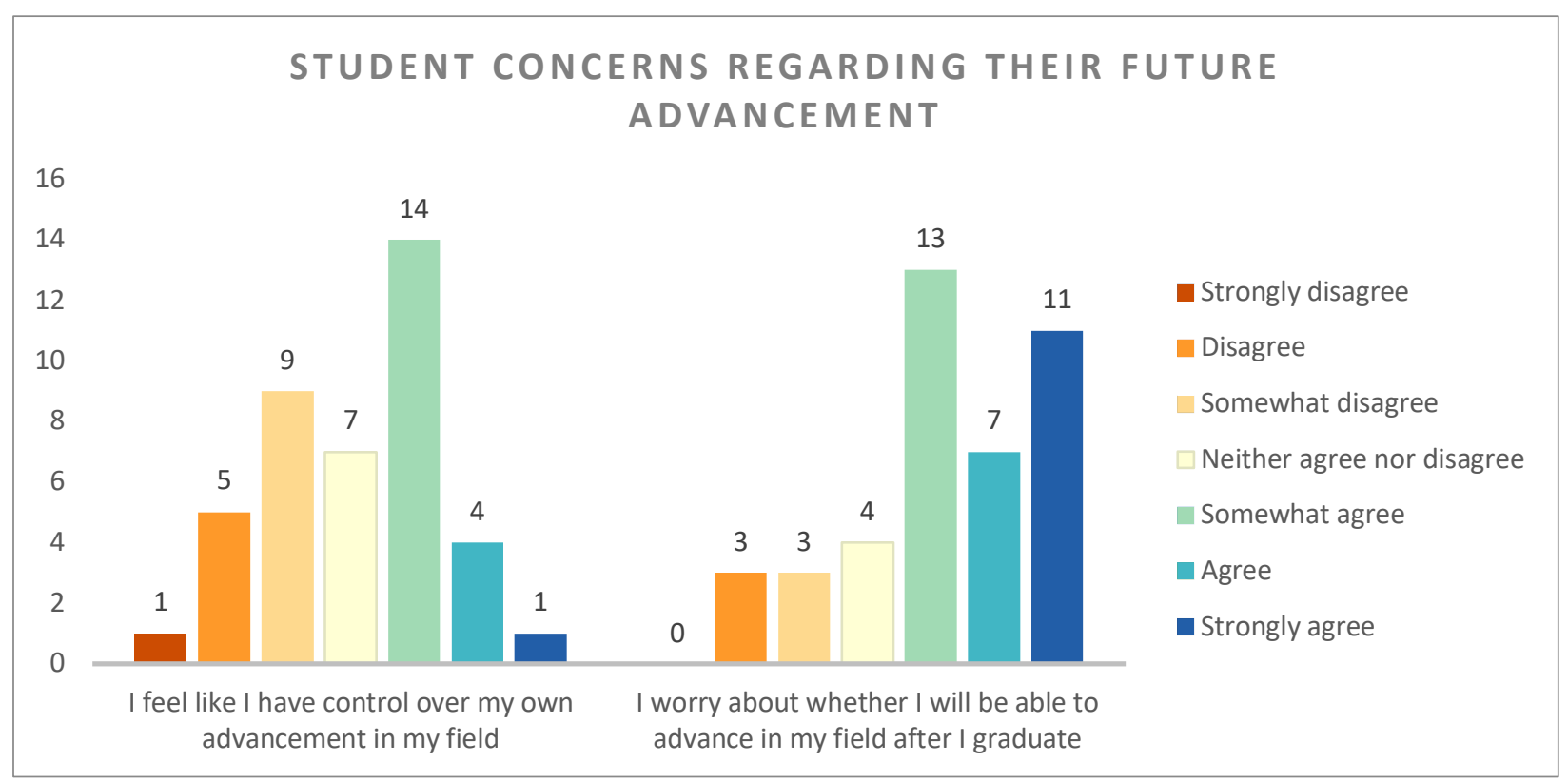

Figure 18. Graduate student concerns regarding their future advancement $(n=41)$.

These results suggest that graduate student concerns about professional advancement are related to a variety of factors, which may include things like optimism and clarity regarding the processes involved, but are not wholly captured by these things. Further inquiry would be necessary to elucidate the additional considerations that affect students' worry regarding their professional advancement. 
Graduate students report feeling welcomed by their departments, and that both students and faculty are supportive of them.

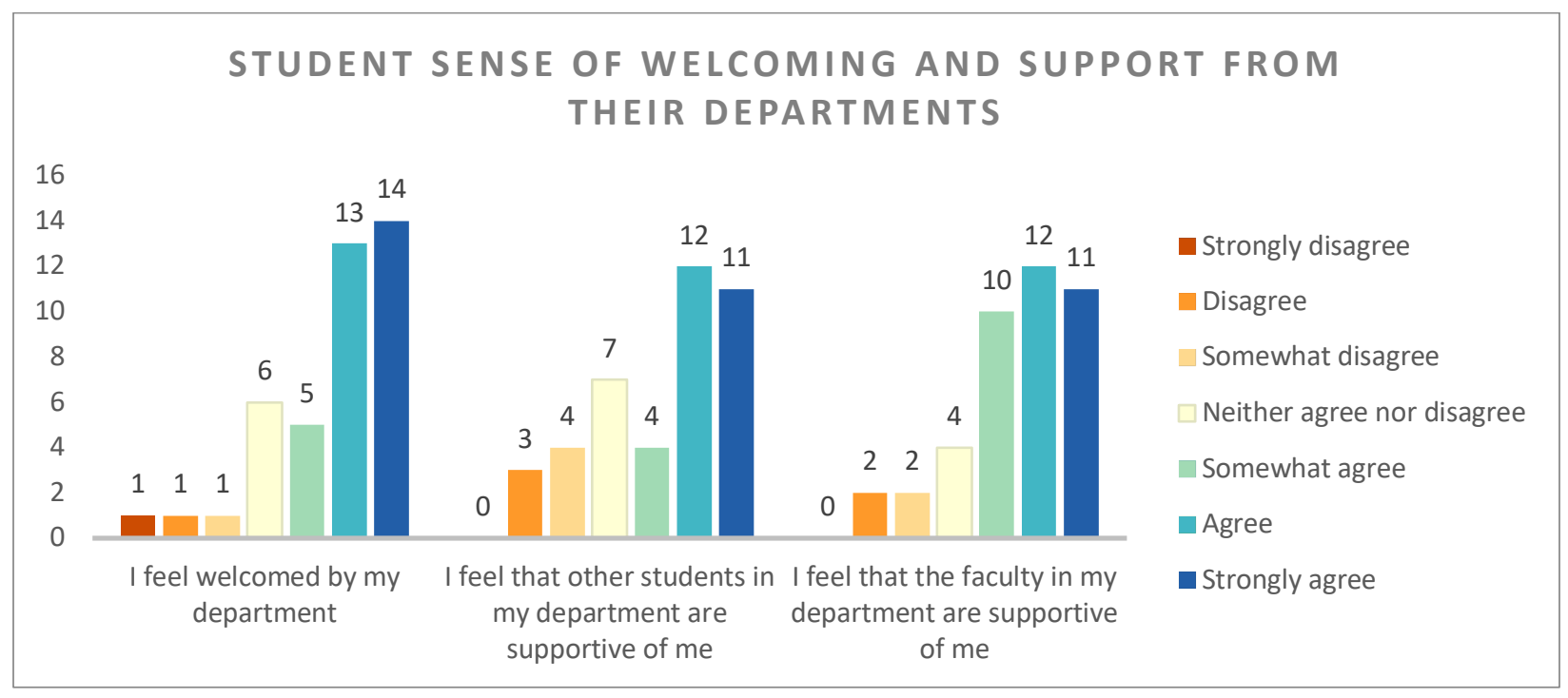

Figure 19. Graduate student responses regarding their sense of welcoming and support in their departments $(\mathrm{n}=41)$.

Similar to faculty, graduate students reported less agreement with the statement "I feel integrated into my department" than with measures of welcome and support. This was reflected in slightly lower measures of self-efficacy as well.

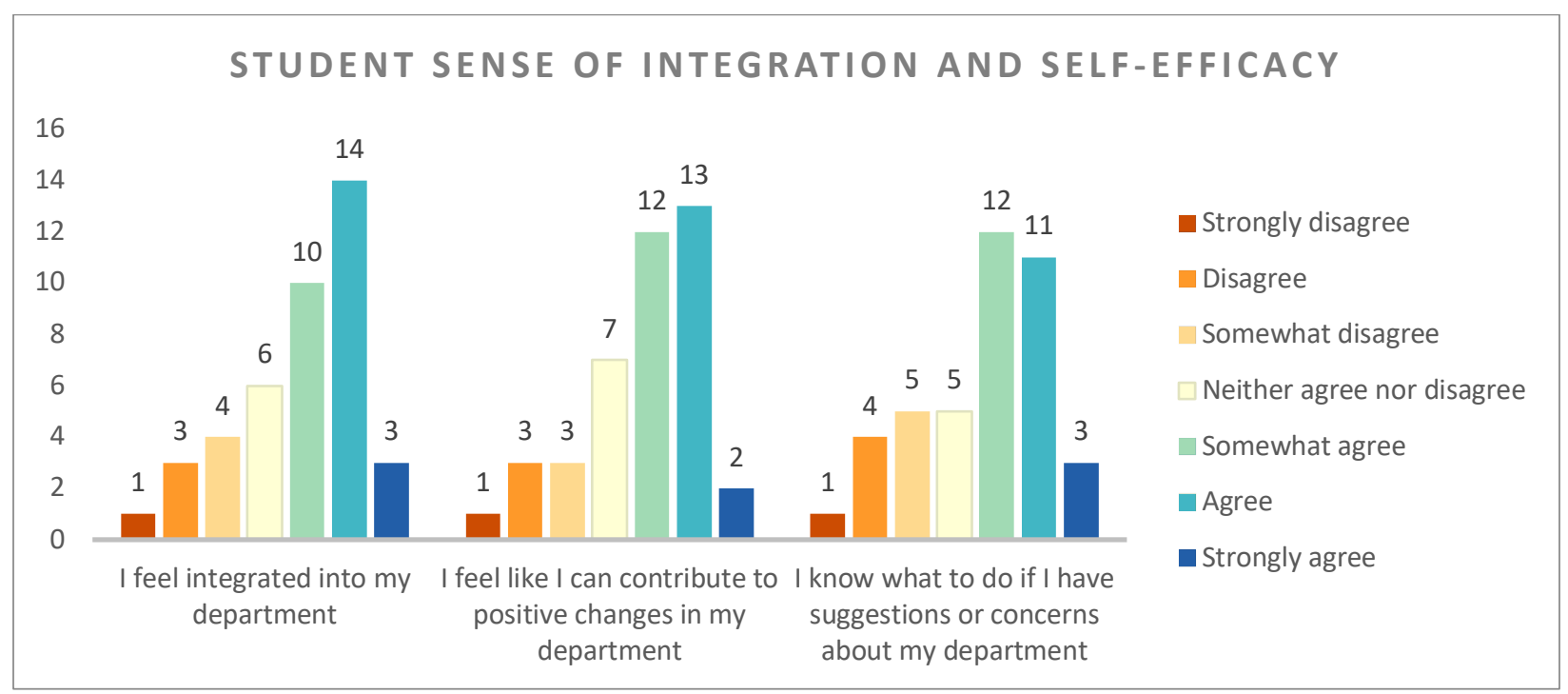

Figure 20. Graduate student sense of integration and self-efficacy related to departmental change $(n=41)$. 


\section{Graduate student service activities}

Nearly all surveyed graduate students participate in some form of service activity. Of the 41 student respondents who completed the questions related to service, only 5 did not participate in any of the listed activities. Community engagement and outreach and participating in a professional development or interest organization (e.g. policy interest groups, women in science groups, etc.) were most common. Students generally agreed that they participate in these activities because they derive personal satisfaction from them.

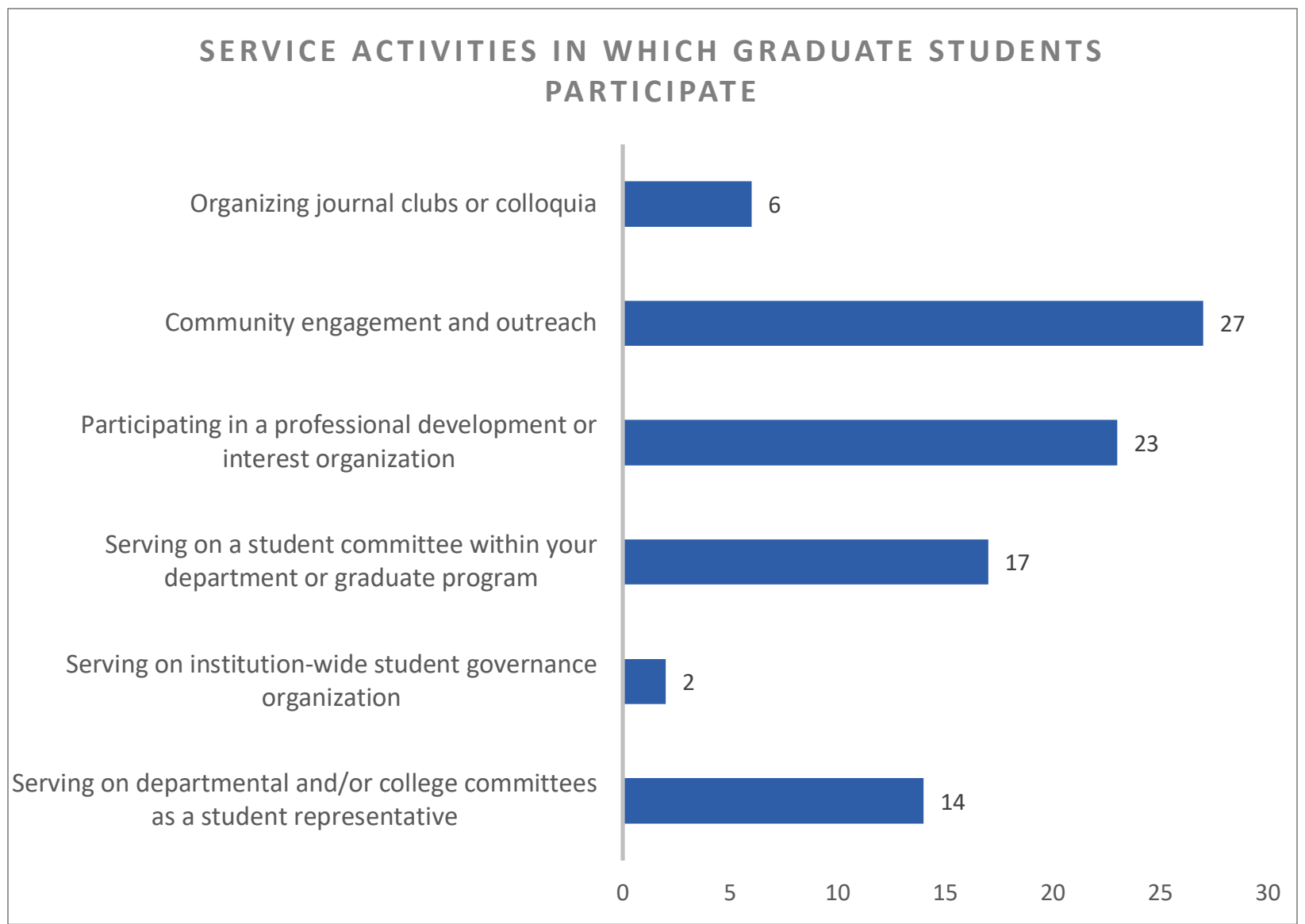

Figure 21. Service-related activities in which graduate students participate. Students were asked to select all activities they participate in from a provided list.

However, graduate students provided widely disparate responses with respect to a concern that service activities could take valuable time away from my academic work. There was a similar lack of consensus regarding whether or not they are discreet about their participation in service activities out of concerns that their graduate advisor may disapprove of how they spend their time. While most student responses ranged from somewhat disagree to strongly agree, this was the only question in the survey for which there were no neutral responses, and one quarter of students somewhat to strongly agreed with the statement. 


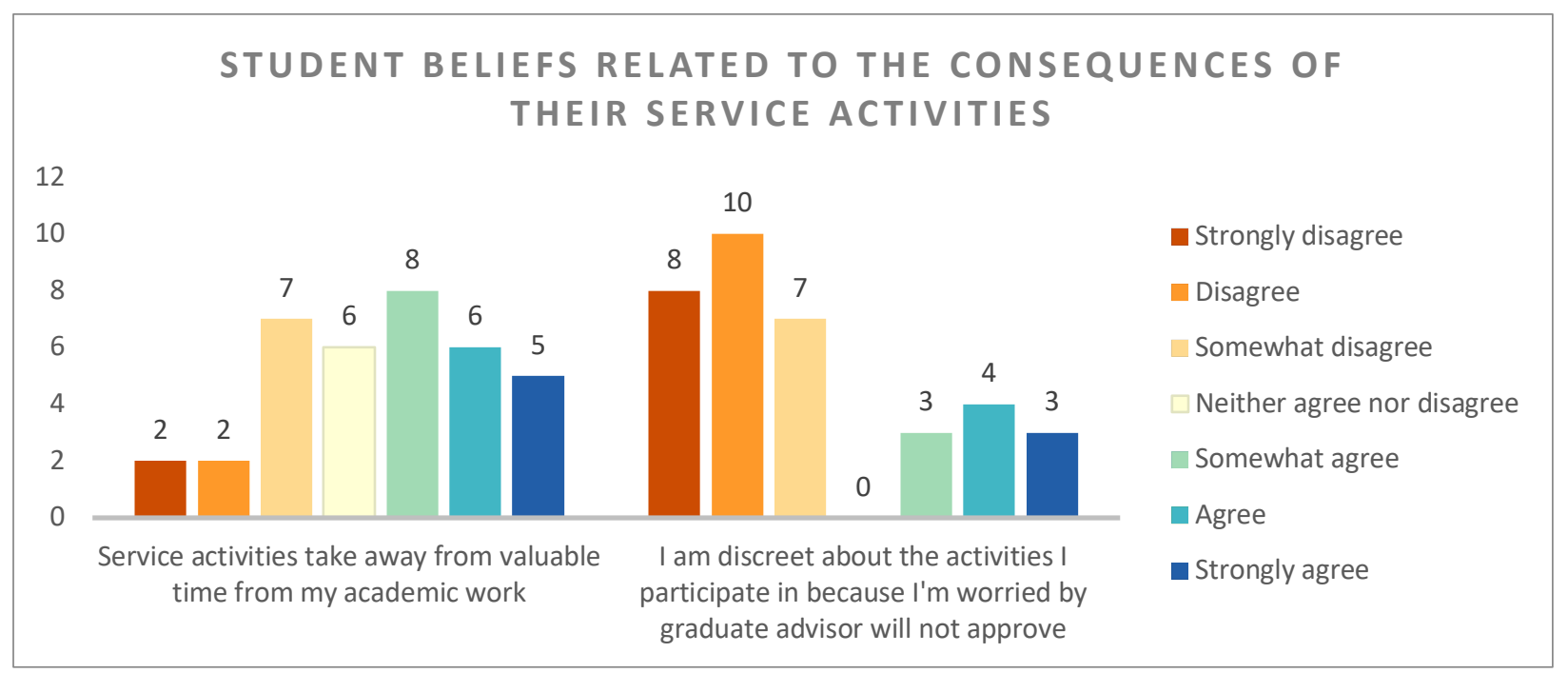

Figure 22. Graduate student beliefs related to the impact of service activities on their academic work $(n=36)$ and the extent to which they exercise discretion about their service activities $(n=35)$.

This indicates that despite compelling evidence that service is a personally satisfying endeavor and one that fulfills unique needs, not all students feel supported to engage in these opportunities. 


\section{Themes from open-ended responses by Faculty}

In addition to the close-ended questions measured quantitatively, faculty were asked to respond to a series of open-ended questions related to their experience of promotion and tenure, and their professional work related to service. Three prominent themes are summarized in the paragraph below; they are information about promotion and tenure, motivations for service, and feedback on the tenure process.

\section{Information about promotion and tenure}

Faculty respondents were asked where they get information about professional advancement including promotion and tenure. Responses varied, though three primary mechanisms were evident: colleagues, formal communications such as university guidelines or department communiques, and formal mentors, including department heads.

Respondents who receive information from colleagues generally did not cite additional sources of information. Those that cited multiple sources, such as mentors, department heads, and formal communications, were less likely to cite colleagues. This indicates that while some faculty are able to avail themselves of formal avenues of guidance, others do not, and thus rely on colleagues (which may include informal mentors or department heads) for advice.

\section{Motivations for participating in service}

Faculty motivations for participating in service can be broadly classified into personal motivations - those related to one's own personal or professional advancement, and community motivations - those related to meeting the needs of other people or communities. Personal motivations include: a desire to cultivate a presence in the department, personal satisfaction, and a need to advance one's own career. Community motivations can include: a sense of duty, advancing important issues, or a desire to be a "team player".

Responses to the question "why do you engage in service activities" are roughly evenly divided between personal and community motivations, with many respondents providing a mix of both sentiments.

"...it is my duty to help others by openly sharing my experience and knowledge, and connecting people to one another. I enjoy participating in respectfully organized activities, review panels, editorial boards, search committees, etc." 


\section{Feedback on the tenure process}

Faculty were also asked two corresponding questions: "What aspects of the promotion and tenure process do you appreciate and want to see retained?" And "If you were department head, what aspects of the promotion and tenure process would you like to reform? What changes would you make?"

Three main themes emerged from these questions. First, that faculty appreciate mentorship, and desire it if they feel mentorship is inadequate. Second, that an open process is valued, and that there are specific ways in which openness can be promoted and maintained that present an opportunity for improvement. And lastly, specific policies around promotion and tenure that promote mentorship and openness are both appreciated and desired.

From the perspective of respondents, mentorship and openness in promotion and tenure go hand in hand. Many faculty respondents specifically cited both as being appreciated, but others simply indicated that "feedback" in different forms was something that they saw as being crucial to their success. Mentors are seen as people who can provide feedback, and offer windows into an otherwise obscure process. Openness can also take the form of clarity in expectations; for example, position FTE as a signal for expectations in a tenure package.

Specific policies regarding mentorship and openness were both cited and suggested. These included formal mentorship committees, allowing assistant professors to attend tenure reviews, and formalized evaluation processes for teaching and service. 


\section{Conclusions}

The overall sense of satisfaction and agreement with promotion and tenure practices at these select university departments was high, perhaps reflecting the selected departments have already given thoughtful attention to promotion and tenure reforms. Transparency and clarity about how faculty are and should be evaluated is one space for additional growth, as is a consideration of how valued service activities can be better incentivized.

These survey results also revealed the extent to which outreach and community engagement are still not formalized as academic activities. Although these activities fulfilled a specific purpose for participants - advocating for science - and was considered to be relatively satisfying, it did not stand out as something that was professionally valued. The sample of survey respondents was overwhelmingly comprised of faculty identifying as white. Though this is partially a reflection of the departments or schools from which the sample was drawn. As departments seek to draw a greater diversity of faculty and graduate students into their halls, revisiting the way activities such as community engagement work are formally valued may prove to be a crucial lever for change.

The overall objective of this study is to understand how departmental scale promotion and tenure reforms emerge, are implemented, and affect people across a department. Response rates for this initial survey were relatively low, reducing the size of the pool of faculty to participate in focused groups originally planned to obtain richer information about the faculty experiences of reforms. The researchers felt that having a small pool of participants would undermine their ability to protect the identity of participants. This concern was greatest for the small number of pre-tenured faculty members and those who identified as a person of color.

The next phase of this study will instead pursue deeper understanding of the experiences of a small number of tenured professors from minoritized and underrepresented groups in academia. The shifted aim is to better understand the systemic barriers to achievement of " $21^{\text {st }}$ Century Professor" portfolios and the compounding challenges for those underrepresented. Through these case studies, researchers hope to expose parts of the system ripe for change that can better align the practices of reward and advancement to the espoused values of universities.

Acknowledgement: The OSU STEM Research Center Team thanks consultants from the Kavli Foundation, the LISTEN Network at the Association of Sciences and Technology Centers, Association of Public and Land-Grant Universities, American Association of Universities, and Howard Hugh's Medical Institute for their contributions to study design and recruitment of departments for the study. Thank you also to the many department chairs, and university administrators who discussed their reward and advancement processes with us and helped to identify departments to include in the study. Most importantly, thank you to the 12 department chairs who generously shared their practices and perspectives and the chairs who encouraged deeper study of their departments. The study was funded by a grant from the Kavli Foundation. 